\title{
The Feeding Regime of Goliath Frog (Conraua goliath) (Boulenger, 1906) in the Equato-guinean Zone of Cameroon
}

\author{
Monthe Moumegni L.F ${ }^{b}$, Yemdjie Mane D.D ${ }^{a}$, Ngouana Tadjong R ${ }^{a}$, Mafouo \\ Sonhafouo $\mathbf{V}^{\mathrm{b}}$. Kana J.R. ${ }^{\mathbf{B}}$ Tchoumboue $\mathbf{J}^{\mathbf{b}}$. \\ ${ }^{a}$ Laboratory of Aquatic Resources, Department of Aquaculture, Institute of Fisheries and Aquatic \\ Sciences, University of Douala. PO Box 7236-Douala-Cameroon. \\ ${ }^{b}$ Laboratory of Animal Nutrition, Department of Animal Science, University of Dschang, PO Box 188 \\ Dschang, Cameroon.
}

*Corresponding author: YEMDJIE MANE Divine Doriane, University of Douala Cameroon; Email: dyemdjie5@yahoo.fr

Article history; Received: October 5th 2020; Revised: October 25 ${ }^{\text {th }} \quad$ 2020; Accepted: December 25th 2020

\begin{abstract}
The feed preferences of Conraua goliath, an endogenous frog in central Africa were assessed in the present study. A total of 65 frogs (22 males, 22 females and 21 unspecified frogs) were obtained from hunters in 3 localities namely: Loum, Penja, and Nlonako in the Moungo division, littoral region of Cameroon. The methods of dissection, measurement, and stomach content analysis were used. The results revealed a large diversity of preys in the stomach namely: myriapods $(25 \%)$, plants leaves and steems $(21.19 \%)$, insects $(19.56 \%)$, indigestible matters (19.56\%), arachnids (4.89\%), crustaceans (4.34\%), mollusks (3.26\%), amphibians $(0.54 \%)$, annelids $(0.54 \%)$ and reptiles $(0.54 \%)$. The numerical percentage and the frequency of myriapods occurrence were significantly $(\mathrm{P}<0.05)$ higher in males captured in the locality of Loum $(100 \%$ and $35.55 \%)$ compared to the females $(28.57 \%$ and $18.18 \%)$. Comparing the state of maturity, the numerical percentage and the frequency of occurrence of insects (100\% and $42.85 \%)$ and indigestible matters (100\% and $42.85 \%)$ were significantly higher in the youngs frogs $(61.11 \%$ and $20.89 \%)$ captured in Loum compared to the adults $(22.22 \%$ and $7.46 \%)$. Frogs of high weight $(>1000 \mathrm{~g})$ recorded significantly $(\mathrm{P}<0.05)$ higher occurrence and numerical frequency of myriapods (100 and 70\%), indigestible and detritus materials $(100$ and $40 \%)$ in low-weight frogs $(<400 \mathrm{~g})$ and plants leaves and steems (50 and $47.36 \%)$ in medium-weight frogs $(400-1000 \mathrm{~g})$. In conclusion, goliath frog is an omnivore fed on a variety of preys and plants according to their availability in the environment.
\end{abstract}

Key words: Conraua goliath, feed preferences, frog, stomacal conten

\section{Introduction}

The world is facing a massive decline in its biodiversity of the amphibians (IUCN, 2020), due to over exploitation and the fragmentation of their habitats (Collins and Storfer, 2003; Bellard et al., 2016). In 2006, among the 4035 amphibian species that depended on water during their life cycle, 1356 approximately 33.6\% were considered threatened (Maxwell et al., 2016). Emerging infectious diseases, such as chytridiomycosis, (Harp et al., 2006; Voordouw et al., 2010; Cunningham et al., 2015), climate change (Walther et al., 2002; Parmesan and Yohe, 2003; Foden et al., 2013; Maxwell et al., 2016), chemical contaminants (Blaustein et al., 2002) and the introduction of predatory species (Kats and Ferrer, 2003) are factors that affect the dynamism of the populations, causing a drop in their number. However, it must be noted that most of the overfished amphibians in the world are edible frogs (Neveu, 2004; Casimir et al., 2016). This is the case of Conraua goliath, a giant African frog listed as endangered species by IUCN (2004).

In Cameroon, goliath frogs is endemic to the Moungo and Nkam regions where its constituted an integral part of the eating habits of the indigenous population. The conservation of this species through its domestication remains the best prospect to ensure its sustainability (Teletchea, 2017). Data on the diet of a species can help to identify the environmental conditions favorable to its development as well as the consequences induced by the degradation of its living environment (Parker and Goldstein, 2004). 
Thus, explaining the fluctuation of their population (Lips et al., 2005) and defined conservation strategies (Batista et al., 2011). Studies on bioecology and feeding habit of the goliath frog are limited. Only few studies have been carried out on neighboring species, in Europe, Asia, America and Africa (Bellakhal et al., 2010; Benício et al., 2011; Camera et al., 2014). The objective of this study is to contribute to the preservation and enhancement of endogenous species through a fairly extensive analysis of its feeding regime in the natural environment.

\section{Material and Methods}

\section{Area of Study}

This study was carried out in the Moungo division, Littoral region of Cameroon (Figure 1), precisely in Loum (LN: $4^{\circ} 41$ 'and LE: 009 $43^{\circ}$ ), Penja (LN: $4^{\circ} 45^{\text {'and LE: 009 }}{ }^{\circ} 5^{\prime}$ ) and Nlonako (LN: $4^{\circ} 40^{\prime}$ and LE: $\left.009^{\circ} 43^{\prime}\right)$ with an average altitude of $665 \mathrm{~m}$.

\section{Relief, Pedology, Climate and Hydrography}

The study area is characterized by three main types of relief, namely the plains along the Moungo river and the surroundings of Penja, the scattered plateaus, and mountain ranges. The soils are dominated by inceptisols (volcanic soils) on its northern and western part. The southern and eastern parts are dominated with sandy soil, silty-sandy and clay-sandy textures. The climate is of equatorial type, strongly influenced by the Guinean monsoon. It is characterized by a short dry season (November to March) and a long rainy season (April to October). The average annual precipitation is $2700 \mathrm{~mm}$, the temperature varies between 20 and $27^{\circ} \mathrm{C}$ and a relative humidity of $75 \%$. The hydrographic network is dense and includes three main rivers namely the Dibombè, Mabombè, Nkam river, multitude of rivers and streams. These rivers are permanent and their rate of flow varies with the season.

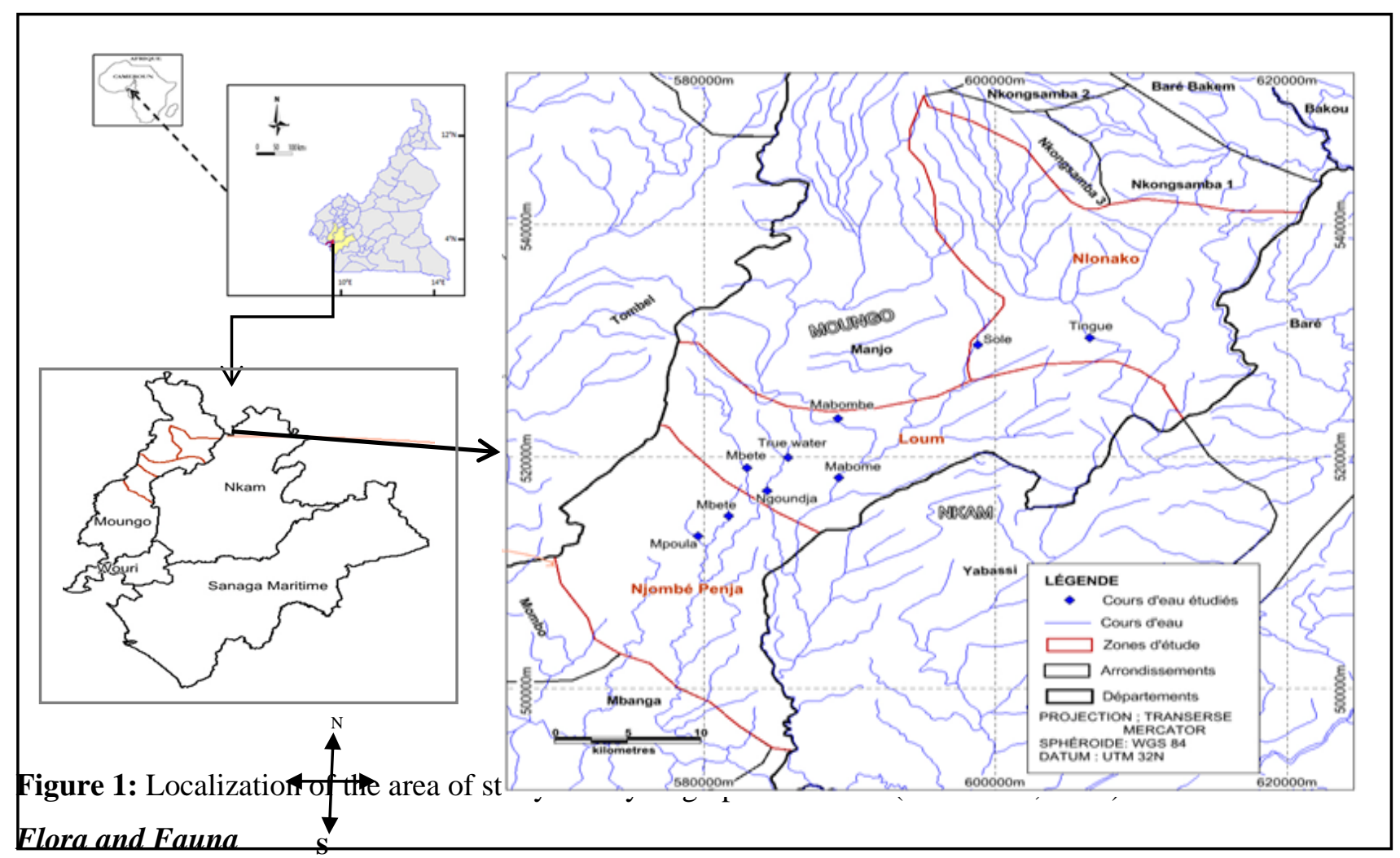

The flora along the rivers is very diverse and dominated by a dense rain forest. We note the presence of industrial plantations (pepper, cocoa, plantain cultivation), Puereria pubescens species as a ground cover plant and a diversity of plant species. The fauna is terrestrial (Potamochoerus porcus, Manis tricuspis, Cercocebus sp., hinds, antelopes, hares, and Arthropods), aerial (Acedinidae, Anatidae, Myliobatidae), and aquatic (Clariidae, Cyprinidae, Cichlidae, Channidae, Potnidae, Channidae, sea turtles, Conraua goliath, Rana esculenta, Conraua robusta, Crocodilia sp., Varanus niloticus). Many predatory snakes and aquatic invertebrates are also encountered there. 


\section{Diet, Gender and Morphometric Characteristics of the Intestine}

A total of 65 specimens of Conraua goliatha were obtained from fishermen in the localities of Loum, Penja and Nlonako (23, 36 and 6 specimens respectively). Frogs were fished at night using trap and hawk. Each sample was weighed using a portable $1 \mathrm{~g}$ precision balance, then sacrificed to keep the stomach contents intact. Thereafter, they were marked according to the locality and the date of capture, then conditioned in a cooler and transported to the laboratory of Ichthyology and Applied Hydrobiology of the University of Dschang, and examined within 12 hours.

The sex of the frogs was determined by observing the colour of the belly (yellow in the male and white in the female), then confirmed after dissection with the presence of eggs in the female. Maturity was determined by the examination of the gonads. Based on this review, frogs were classified as immature (undifferentiated sex) or mature (males, females). The frogs were carefully dissected using a pair of scissors and a scalpel. The digestive system of the frogs were removed, the intestine cut just below the esophagus, at the level of the anal opening and then unrolled. The length of the intestine (Li), was measured from the pyloric valve to the anus using a $0.1 \mathrm{~cm}$ tape and the weight of the intestine (Wi) was obtained using an electronic scale balance (Sartorius Competence) of $0.01 \mathrm{~g}$ precision. The analysis of the stomach contents according to the method described by Hynes (1950) was used to determine the nature of food consumed by frogs. Thus, the stomach of each frog was cut just below the esophagus and stored in $10 \%$ formalin to keep the stomach contents intact. The contents were emptied in a petri dish and then weighed. The length and width of the stomach were measured using the caliper. The stomach contents were identified at a taxonomic level up to the family with respect to the state of conservation of the stomach using the identification keys of Needham and Needham (1974), Delvare and Abertenc (1989) and Klass-Douwe and Dijkstra (2014).

The macroscopic food fragments were counted in petri dishes, with the eyes and / or under a binocular stereoscopic magnifier (magnification $\times 10$ ) and the observation test of the microscopic fragments were carried out using an optical microscope (magnification $\mathrm{x} 40$ ). The elements thus identified were grouped into feed categories or items. The volume of each prey was estimated using the ellipsoid formula: $\mathrm{V}=4 / 3 \Pi * 2(1 / 2) 2 * \mathrm{~L} / 2$ (where, $\mathrm{L}=$ length; 1 = width; $\mathrm{V}=$ volume of prey; $\Pi=3.14$ ) (Magnusson, 2003). Stomach containing food fragments or filled stomach, totally, half or a quarter filled and those without any food fragments (empty stomach) were evaluated (Tiogue et al., 2015).

\section{Data Collected}

Analysis of the stomach contents was used to calculate the following parameters of food preferences: - Frequency of occurrence (\% O) (Rosecchi and Nouaze, 1987; Gray et al., 1997)

$\% \mathrm{O}=\left(\mathrm{F}_{\mathrm{i}} / \sum \mathrm{F}_{\mathrm{i}}\right) \times 100$, with $\mathrm{F}_{\mathrm{i}}=\mathrm{n}_{\mathrm{i}} / \mathrm{NT}$ and $\mathrm{F}_{\mathrm{i}}=$ Frequency of item $\mathrm{i} ; \mathrm{n}_{\mathrm{i}}=$ number of stomachs containing item $\mathrm{i}$ and $\mathrm{N}_{\mathrm{T}}=$ Total number of full stomachs examined.

- Numerical percentage (\% N) (Lauzanne, 1975; Hyslop, 1980):

$\% \mathrm{~N}=\left(\mathrm{n}_{\mathrm{xi}} / \mathrm{N}_{\mathrm{xt}}\right) \times 100$, with $\mathrm{n}_{\mathrm{xi}}=$ Total number of individuals in item $\mathrm{i}$; and $\mathrm{N}_{\mathrm{xt}}=$ Total number of all food items.

- Percentage weight $(\% \mathrm{~W})\left(\right.$ Lauzanne, 1977): $\% \mathrm{~W}=\mathrm{W}_{\mathrm{T}} \times 100 / \mathrm{W}_{\mathrm{t}}$, with $\mathrm{W}_{\mathrm{T}}=$ Total weight of item $\mathrm{i}$; and $\mathrm{W}_{\mathrm{t}}=$ total weight of all food items identified.

- Volumetric percentage (\%V) (Hyslop, 1980): $\% \mathrm{~V}=\mathrm{V}_{\mathrm{p}} / \mathrm{V}_{\mathrm{i}} * 100$, where $\% \mathrm{~V}=$ volumetric percentage, $\mathrm{V}_{\mathrm{p}}=$ volume of food category and $\mathrm{V}_{\mathrm{i}}=$ volume of the intestine or stomach.

- Relative index of importance (\%RII) (Pinkas et al., 1971): \% RII $=\% \mathrm{O} \times(\% \mathrm{~N}+\% \mathrm{O})$.

The method of Hureau (1970) modified by Geistdoerfer (1975) analyses the stomach contents and classify the prey:

- Preferential (PMP) and occasional (OMP) main prey: If $\mathrm{Q}>100$ and $\mathrm{F}>30 \%$ and $\mathrm{Q}>100$ and $\mathrm{F}<30 \%$ respectively

- Frequent secondary prey (FSP) and accessories (PSA): If $10<\mathrm{Q}<100$ and $\mathrm{F}>10 \%$ and $10<\mathrm{Q}<100$ and $\mathrm{F}<10 \%$ respectively 
- Complementary prey of the first order (CPFO) and of the second order (CPSO): $\mathrm{Q}<10$ and $\mathrm{F}>10 \%$ and $\mathrm{Q}<10$ and $\mathrm{F}<10 \%$.

Where $\mathrm{F}$ is the frequency index of a prey with $\mathrm{F}=$ Number of stomachs containing the item $\mathrm{i} \times 100 /$ Total number of full stomachs, $\mathrm{Q}$ is the food quotient with: $\mathrm{Q}=\% \mathrm{C}_{\mathrm{w}} \times \% \mathrm{C}_{\mathrm{n}}$ or $\mathrm{C}_{\mathrm{n}}$ being the percentage by number and $\mathrm{C}_{\mathrm{w}}$ is the percentage by weight of a prey. $\% \mathrm{C}_{\mathrm{n}}=100 \times$ Number of individuals of each type of prey / Total number of prey ingested per individual and $\% \mathrm{C}_{\mathrm{w}}=100 \times$ Weight of each type of prey consumed / Total weight of prey ingested per individual.

\section{Statistical Analysis}

The data collected were subjected to analysis of variance (ANOVA). Where there was significant differences between the means, Duncan's Multiple Range test was applied to separate them at 5\% significance level. The statistical software SPSS 20.0 (Statistical Package for Social Sciences) was used for these analysis and the map location of the capture sites with the MAPINFO 7.8 software.

\section{Results}

The different categories of prey consumed by Conraua goliath in the localities of Loum, Penja and Nlonako are summarized in Table 1. It appears that the preys were divided into 5 categories, namely preferential primary prey (diplopod, indigestible matters and detritus), frequent secondary prey (decapod, beetle and plant materials), accessory secondary prey (gastropod), first-order complementary prey (aranea, chilopod, orthoptera) and second order complementary prey (anoure, squamata, odonate, hemiptera, hymenoptera, dermaptera, annelid, diptera). These include the presence of terrestrial, aquatic and semi-aquatic prey. The diplopods and plant matters were more numerous and abundant in the stomachs. The percentage weight and relative index of importance were respectively higher. Indigestible matter and litter have a high frequency of occurrence in the stomach.

Table 1: Category of food (taxon) consume by Conraua goliath

\begin{tabular}{|c|c|c|c|c|c|c|c|}
\hline \multicolumn{8}{|l|}{ Categories of feed } \\
\hline & $\mathrm{N}(\%)$ & $\mathrm{W}(\%)$ & $\mathrm{V}(\%)$ & $\mathrm{RII}(\%)$ & $\mathrm{O}(\%)$ & $\mathrm{Q}(\%)$ & Classification \\
\hline Annelid & 1.08 & 0.01 & 0.01 & 3.92 & 3.57 & 0.02 & $\mathrm{Q}<10 \%$ and $\% \mathrm{O}<10 \%:(\mathrm{CPSO})$ \\
\hline Aranea * & 4.89 & 0.29 & 0.11 & 80.45 & 16.07 & 1.43 & $\mathrm{Q}<10 \%$ and $\% \mathrm{O}>10 \%:(\mathrm{CPFO})$ \\
\hline Chilopod & 3.80 & 1.77 & 0.93 & 59.22 & 12.5 & 6.74 & $\mathrm{Q}<10 \%$ and $\% \mathrm{O}>10 \%:(\mathrm{CPFO})$ \\
\hline Coleoptera* & 11.41 & 1.91 & 0.46 & 403.00 & 33.92 & 21.89 & $10 \%<\mathrm{Q}<100 \%$ and $\% \mathrm{O}>10 \%:(\mathrm{FSP})$ \\
\hline Decapode * & 4.34 & 10.65 & 23 & 390.75 & 14.28 & 46.32 & $10 \%<\mathrm{Q}<100 \%$ and $\% \mathrm{O}>10 \%:(\mathrm{FSP})$ \\
\hline Dermaptera & 2.17 & 0.03 & 0,05 & 11.96 & 5.35 & 0.08 & $\mathrm{Q}<10 \%$ and $\mathrm{t} \% \mathrm{O}<10 \%:(\mathrm{CPSO})$ \\
\hline \multicolumn{8}{|l|}{ Indigestibles matter } \\
\hline and detritus & 20.10 & 7.56 & 1.58 & 1045.71 & 48.21 & 152.11 & $\mathrm{Q}>100 \%$ and $\% \mathrm{O}>30 \%:(\mathrm{PMP})$ \\
\hline Diplopod & 20.65 & 59.81 & 10.62 & 1396.18 & 44.64 & 1235.29 & $\mathrm{Q}>100 \%$ and $\% \mathrm{O}>30 \%:(\mathrm{PMP})$ \\
\hline Diptera & 1.08 & 0.02 & 0.0049 & 3.89 & 3.57 & 0.03 & $\mathrm{Q}<10 \%$ and $\% \mathrm{O}<10 \%:(\mathrm{CPSO})$ \\
\hline Gasteropod * & 3.260 & 8.06 & 1.99 & 37.51 & 7.14 & 26.28 & $10 \%<\mathrm{Q}<100 \%$ and $\% \mathrm{O}<10 \%:(\mathrm{PSA})$ \\
\hline Hemiptera * & 0.54 & 1.42 & 0.60 & 2.04 & 1.78 & 0.77 & $\mathrm{Q}<10 \%$ and $\% \mathrm{O}<10 \%:(\mathrm{CPSO})$ \\
\hline Hymenoptera & 0.54 & 0.003 & 0.004 & 0.97 & 1.78 & 0.001 & $\mathrm{Q}<10 \%$ and $\% \mathrm{O}<10 \%:(\mathrm{CPSO})$ \\
\hline Plant matters & 20.65 & 1.55 & 47.60 & 1950.25 & 28.57 & 32.04 & $10 \%<\mathrm{Q}<100$ and $\% \mathrm{O}>10 \%:($ FSP $)$ \\
\hline Odonate & 0.54 & 0.09 & 0.016 & 0.99 & 1.78 & 0.05 & $\mathrm{Q}<10 \%$ and $\% \mathrm{O}<10 \%:(\mathrm{CPSO})$ \\
\hline Orthoptera & 3.80 & 1.73 & 0.41 & 52.794 & 12,5 & 6.60 & $\mathrm{Q}<10 \%$ and $\% \mathrm{O}>10 \%:(\mathrm{CPFO})$ \\
\hline Anoure & 0.54 & 3.96 & 2.53 & 5.50 & 1,78 & 2.15 & $\mathrm{Q}<10 \%$ and $\% \mathrm{O}<10 \%:(\mathrm{CPSO})$ \\
\hline Squamata & 0.54 & 1.05 & 10.02 & 18.87 & 1.78 & 0.57 & $\mathrm{Q}<10 \%$ and $\% \mathrm{O}<10 \%:(\mathrm{CPSO})$ \\
\hline
\end{tabular}


The categories of food illustrated in photo 1 was composed of detritus, indigestibles matters, plants (plant matter), invertebrate (insects, crustacean, molluscs, myriapod, arachnid and annelid) and vertebrate (amphibians and reptile).

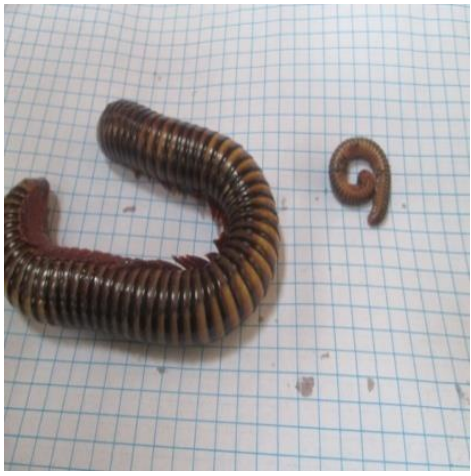

A

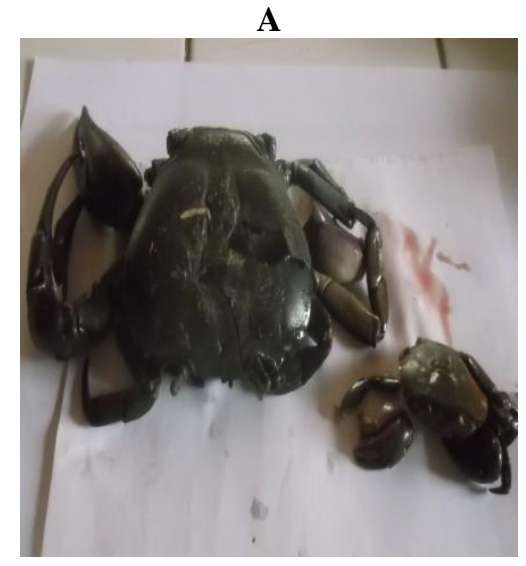

D

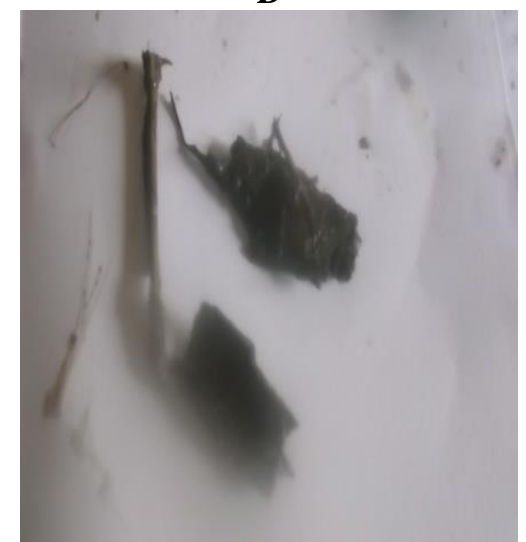

G

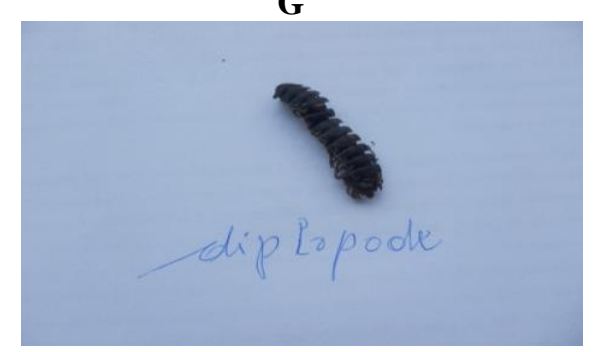

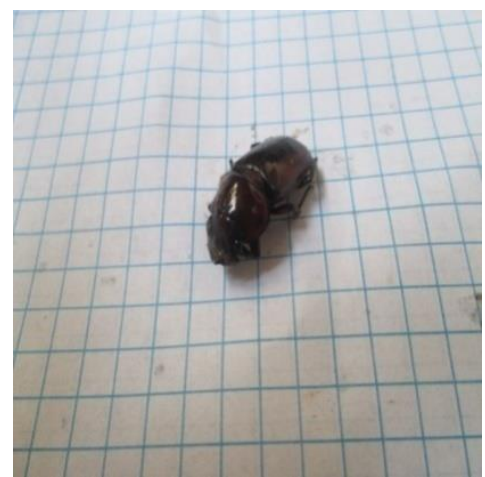

B

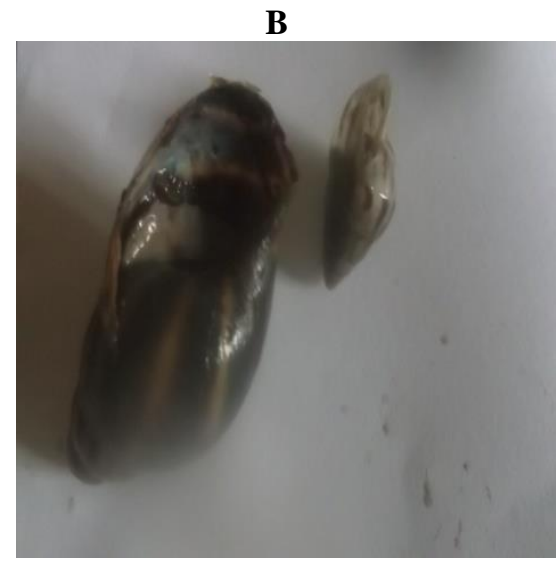

$\mathbf{E}$

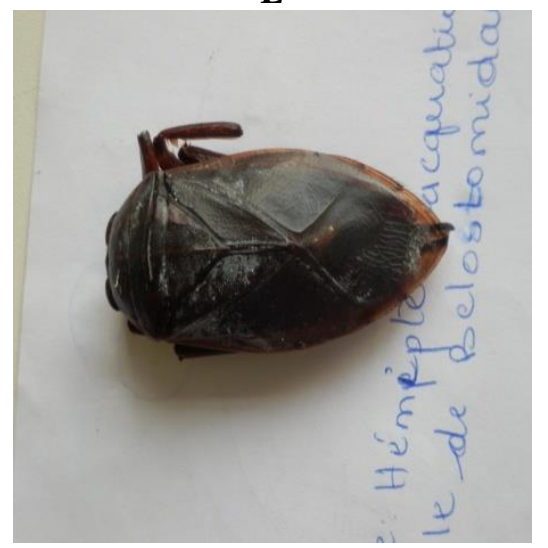

$\mathbf{H}$

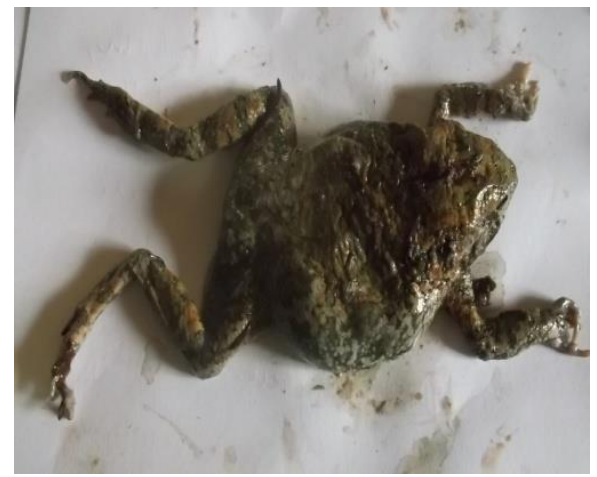

C

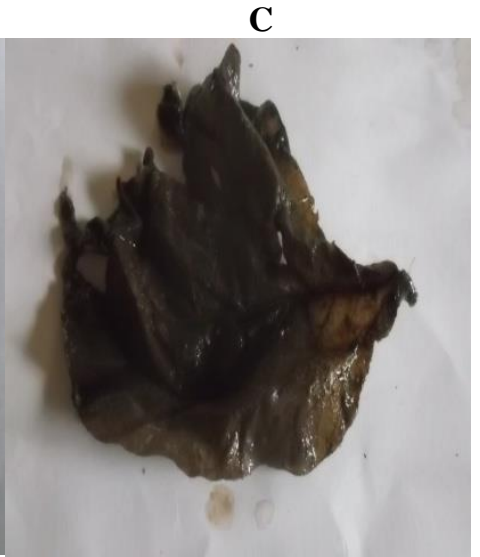

$\mathbf{F}$

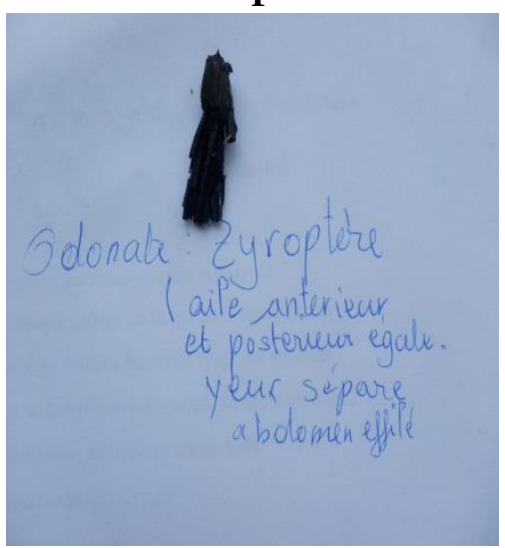

I

\section{J}

Figure 1: Galery of food categories consumed by Conraua goliath (a) Diplopode; (b) beetle; (c) amphibian; (d) decapod (e); gastropod (f); plant matter (g) indigestible matter; (h); hemiptera; (i) odonate; (j) chilopod. 
The frequency of occurrence of prey according to the gender and state of maturity as illustrated in Figures 2 and 3 shows that, irrespective of the factors considered, organic matter of animal origin was significantly higher $(\mathrm{P}<0.05)$ in the stomachs of Conraua goliath. Their frequency of occurrence was significantly represented $(\mathrm{P}<0.05)$ in the stomachs of males $(95.23 \%)$. The values obtained in adults $(86.48 \%)$ and youngs $(89.47 \%)$ frogs were comparables. The frequency of occurrence $(42.85 \%)$ of plant organic matter recorded in males were significantly higher compared to the frequency of indigestible and detritus materials $(19.04 \%)$.

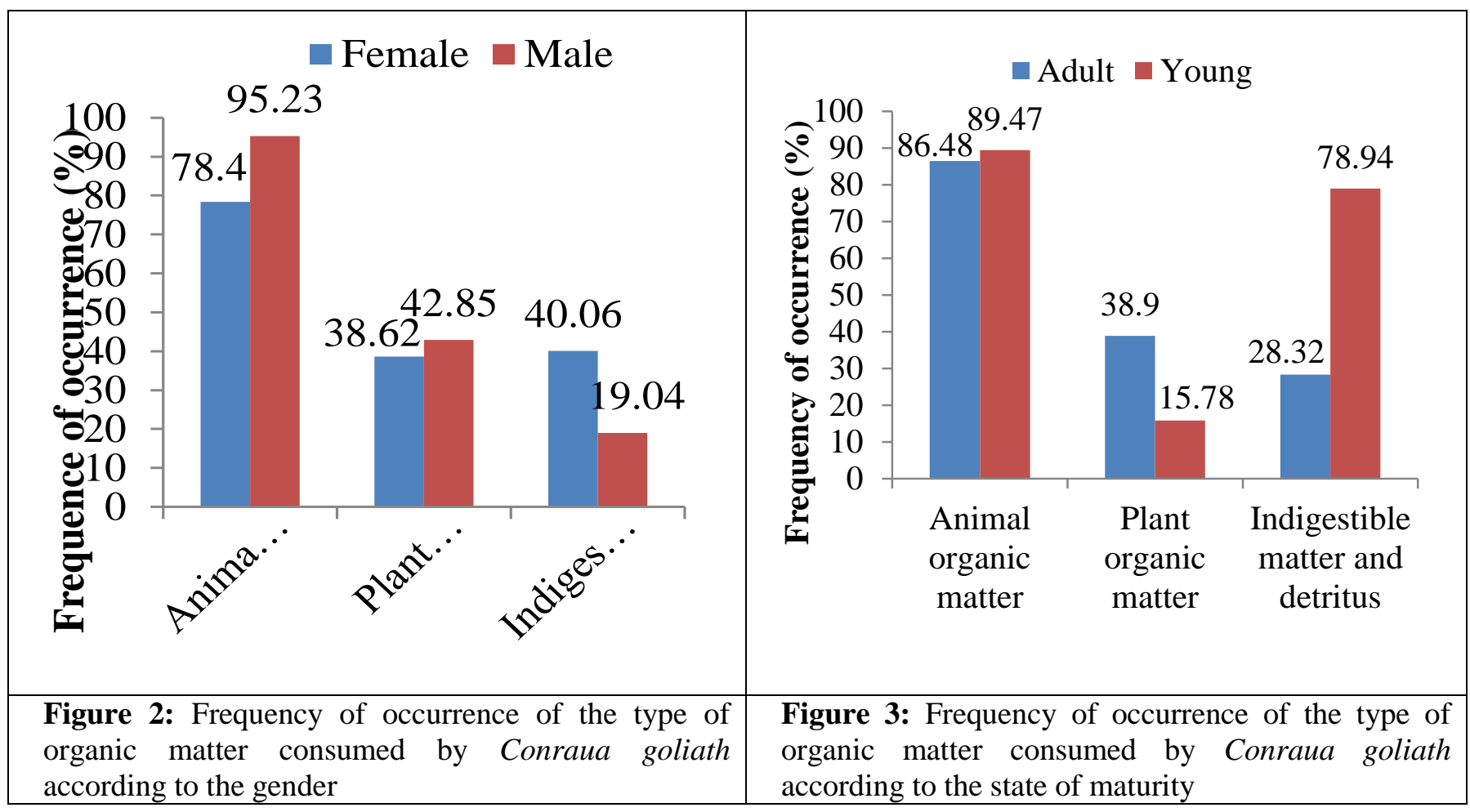

Food Preferences by Locality and Gender of Conraua goliath
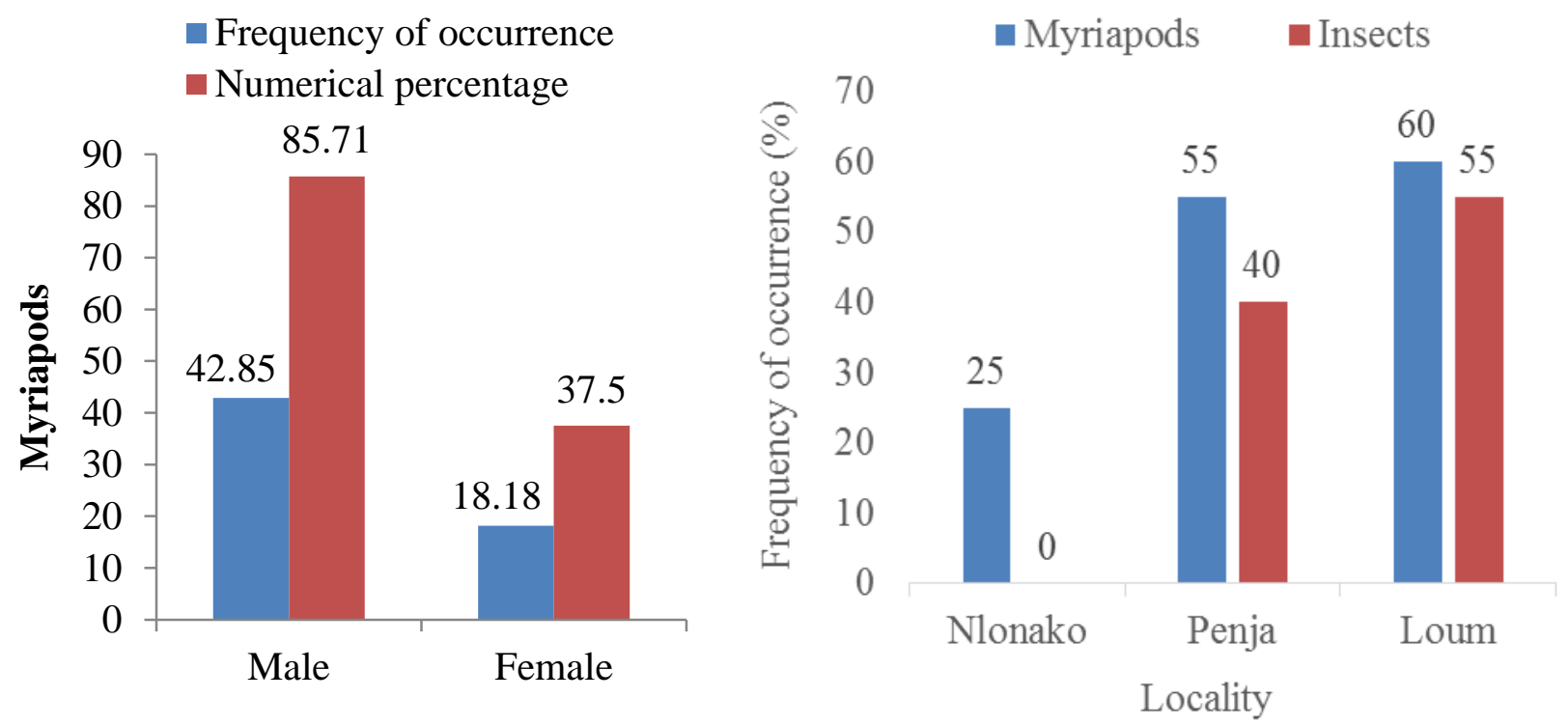

Figure 4: Frequency of occurrence and numerical percentage of myriapods by gender of Figure 5: Frequency of occurrence of myriapods and Conraua goliath 
The frequency of occurrence and the numerical percentage of myriapods (figure 4) recorded significantly higher values in males (42.85 and $85.71 \%$ ) compared to females (18.18 and $37.50 \%)$. The prey was more diversified in the stomachs of frogs captured at Loum, followed by Penja and Nlonako respectively. Reptiles and annelids were absent irrespective of the location and gender. With equal diversity, the myriapods were significantly $(\mathrm{P}<0.05)$ more frequent and numerous regardless of the locality considered. Depending on the localities (figure 5), myriapods and insects were significantly less frequent ( 25 and $0 \%$ ) in Nlonako compared to the frogs from Penja (55 and 40\%) and Loum (60 and 55\%). Food Preferences According to Locality and State of Maturity of Conraua goliath

Food preferences of Conraua goliath with respect to the locality and state of maturity (Figures 6) indicate that regardless of the localities and states of maturity, frogs mainly consumed myriapods (25\%), plant materials $(21.19 \%)$, insects (19.56\%), indigestible materials and detritus $(19.56 \%)$, arachnids $(4.89 \%)$, crustaceans $(4.34 \%)$, gastropods (3.26\%), annelids $(0.54 \%)$, amphibians $(0.54 \%)$ and reptiles $(0.54 \%)$. Depending on the locality, insects were more frequent in the stomachs of adults frogs found in Loum (table 2). In this particular locality, the frequency of occurrence, of insects (100 and $42.85 \%)$ and indigestible matter (100 and $42.85 \%)$ were significantly higher in youngs frogs captured in comparison to the adults frogs respectively (61.11 and 20.89\%) and (22.22 and $7.46 \%)$.

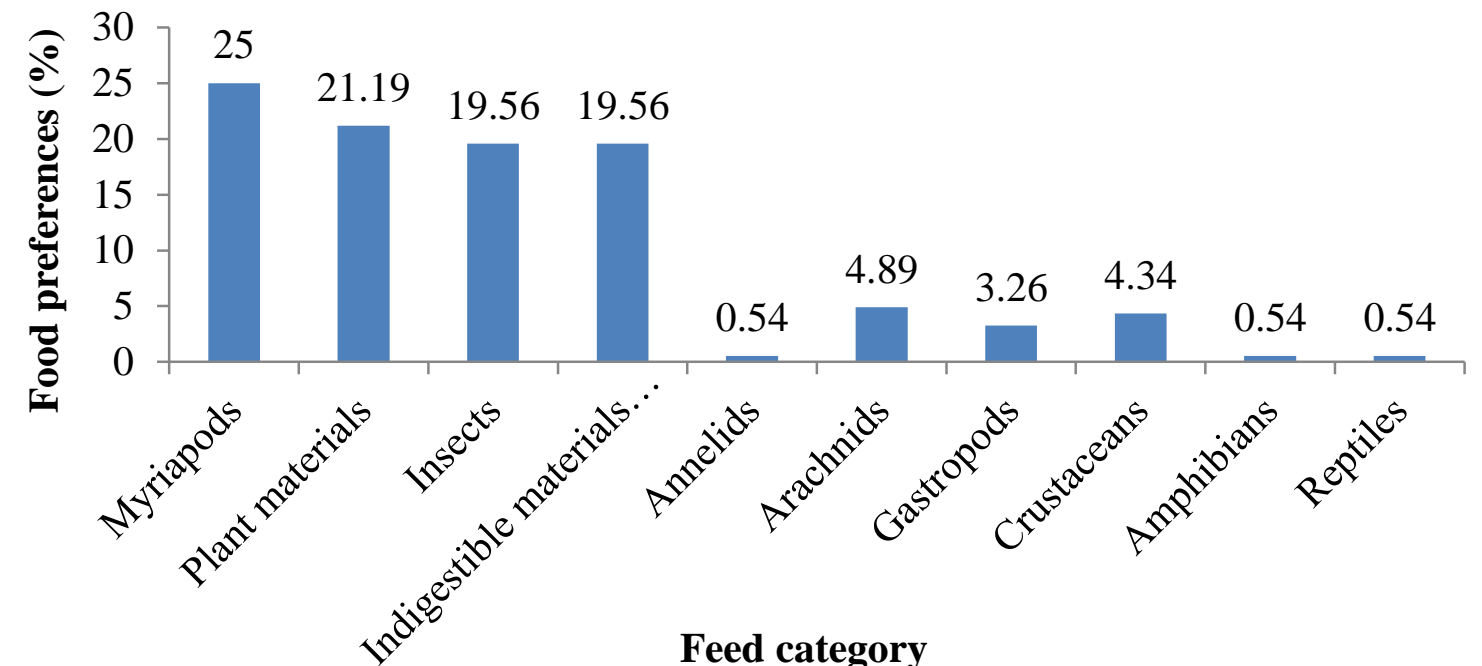

Figure 6: Food preferences of Conraua goliath regardless the locality and state of maturity

Table 2: Frequency of occurrence and numerical percentage of insects and indigestible matter by state of maturity in Loum

\begin{tabular}{lcccc}
\hline & \multicolumn{2}{c}{ Insects } & \multicolumn{2}{c}{ Indigestible matters } \\
\cline { 2 - 4 } & Frequency of occurrence & numerical percentage & Frequency of occurrence & numerical percentage \\
\hline Youngs frogs & 100 & 42.85 & 100 & 42.85 \\
Adults frogs & 61.11 & 20.89 & 22.22 & 7.46 \\
\hline
\end{tabular}

\section{Food Preferences Based on Weight}

The food preferences of Conraua goliath with respect to weight summarized in table 3 shows that the preys were more diversified (9 feed categories) in the stomach of frogs of low weight $(<400 \mathrm{~g})$, moderately diversified ( 7 categories) in frogs of high weight $(>1000 \mathrm{~g})$, and less diversified (6 categories) in those of medium weight (400 to $1000 \mathrm{~g}$ ). Annelids were present only in frogs of low 
weight. Frogs of high weight $(>1000 \mathrm{~g})$ recorded significantly $(\mathrm{P}<0.05)$ higher occurrence and numerical frequency of myriapods (100 and 70\%), indigestible and detritus materials (100 and 40\%) in low-weight frogs $(<400 \mathrm{~g})$ and plants leaves and steems $(50$ and $47.36 \%)$ in medium-weight frogs $(400-1000 \mathrm{~g})$.

Table 3: Food preferences with respect to weight of Conraua goliath

\begin{tabular}{|c|c|c|c|}
\hline Food categories & $<400 \mathrm{~g}$ & $400-1000 g$ & $>1000 \mathrm{~g}$ \\
\hline Annelids & + & - & - \\
\hline Arachnids & + & - & + \\
\hline Myriapods & + & + & + \\
\hline Insects & + & + & + \\
\hline Crustaceans & + & + & + \\
\hline indigestible and detritus materials & + & + & + \\
\hline Gasteropods & + & - & + \\
\hline Plant materials & + & + & + \\
\hline Amphibians & - & + & - \\
\hline Reptiles & + & - & - \\
\hline
\end{tabular}

(+): present; (-): absent

\section{Discussion}

The analysis of the stomach contents of Conraua goliath shows that this frog consumes a wide varieties of feed. Feed from animal origin are predominant both in frequency of occurrence, and in numerical percentage suggesting that this frog is omnivorous with carnivorous tendency. These preys are terrestrial, aquatic and semi-aquatic in nature, indicating that frogs foraged in water and on land. This result corroborates the results of the studies carried out in Tunisia on Rana saharica, in which adults consume $96.32 \%$ of terrestrial preys and 3.68\% of aquatic preys (Bellakhal et al., 2010). Study on Rana ridibunda in Russia (Mordovia) revealed that this species fed mainly on aquatic preys (Ruchin and Ryzhov's, 2002). Other investigations on the diet of ranidae revealed that they fed exclusively on terrestrial preys (Berry, 1965; Jenssen and Klimstra, 1966; Beschkov, 1970; Whitaker et al., 1981; Hirai and Matsui, 1999; 2001a). Feed from plant origin is also frequent in the stomachs in high number irrespective of the factor of variation considered. The ingestion of plant materials is recurrent in many anurans (Batista et al., 2011; Maragno and Souza, 2011; Pazinato et al., 2011; Sabagh et al., 2012). However, many authors reported that they are accidentally ingested during food capture (Whitaker et al., 1977; Evans and Lampo, 1996; Anderson et al., 1999; Teixeira et al., 1999).

The variability in the frequency of occurrence and the number of feed with respect to locality, sex, state of maturity, size and weight of Conraua goliath is attributed to the fact that the choice of preys is above all it's availability and also edaphic characteristics of the surrounding environment (Werner et al., 1995; Das, 1996; Low and Török, 1998; Hirai and Matsui, 1999; 2001b), due to the dynamics of prey populations (Hirai and Matsui, 2001a; Maneyro et al., 2004; Santos et al., 2004). This variability can also be linked to the fact that in the same species, there would be disparities in the diet according to gender and size. Studies on Leptodactylus latrans in Uruguay and Argentina shows great overlap in diet that exists between males and females (Maneyro et al., 2004; Sanabria et al., 2005). However, certain investigations attested that there is no difference in diet between the gender. This is the case of Rhinella scitula in Brazil (Maragno and Souza, 2011) and Ptychadena mascareniensis in Madagascar (Vences et al., 2004).

The composition of Conraua goliath diet is more diversified in youngs ones, thus reflecting opportunistic and passive eating behaviors. Studies on the diet of genus Leptodactylus, show that there is a large quantity of larvae and more sedentary groups, describing an opportunistic feeding behavior (Maneyro et al., 2004; Rodrigues et al., 2004, Sanabria et al., 2005; De Carvalho et al., 2008; Solé et al., 2009; Solé and Rödder, 2010). This can be explained by the fact the consumption of larger prey in small numbers by frogs is sufficient to cover their needs, unlike small prey. 


\section{Conclusion}

The goliath frog is an omnivore with a carnivorous tendency and fed on a variety of preys according to their availability in the environment. Preys are more diversified in youngs frogs than adults ones with the myriapods been the more frequent and numerous.

\section{Acknowledgement}

Grateful acknowledgement is expressed to the international fund for Science (IFS) for the financial support of the present work. The authors wish to thank all participating fishermen and laboratory technicians for their cooperation.

\section{Author's Contributions}

MONTHE MOUMEGNI Liliane Fleurette, YEMDJIE MANE Divine Doriane, NGOUANA TADJONG Ruben and MAFOUO SONHAFOUO Vanessa went to the field to carry out the research and collect the samples. KANA Jean Raphael supervised the overall research work. MONTHE MOUMEGNI Liliane Fleurette, YEMDJIE MANE Divine Doriane and KANA Jean Raphael wrote the first draft before being revised by NGOUANA TADJONG Ruben, MAFOUO SONHAFOUO Vanessa and TCHOUMBOUE Joseph and approved by all the authors.

\section{References}

Anderson AM. Haukos DA. Anderson JT 1999. Diet composition of three anurans from the Playa. Wetlands of Northwest Texas. Copeia, 6, 515-520. DOI: 10.2307/1447502

Batista RC. De-Carvalho CB. Freitas EB. Franco SC. Batista CC. Coelho WA. Faria RG 2011. Diet of Rhinella schneideri (Werner, 1894) (Anura: Bufonidae) in the Cerrado, Central Brazil. Herpetology Notes, $4: 17-21$.

Bellakhal M. 2010. Le régime alimentaire de la grenouille verte d'Afrique du nord, Rana saharica. Revista electrónica de Veterinaria, 11: 1695-7504

Bellard C. Cassey P. Blackburn TM 2016. Alien species as a driver of recent extinctions. Biology Letters, 12:1744-9561. https://doi.org/10.1098/rsbl.2015.0623

Benício T., Rodrigues R. A. \& Salles R. O. L. (2011). Herbivoria em Rhinella icterica (Amphibia: Anura: Bufonidae). Saúde \& Ambiente em Revista 6: 01-03. montane region of Kyoto, Japan. Journal of Herpetology, 36, 719-723. http://dx.doi.org/10.1590/S1676-06032012000400027

Berry PY 1965. The diet of some Singapore Anura (Amphibia). Journal of Zoology, 144: 163-167. https://doi.org/10.1111/j.1469-7998.1965.tb05171.x

Beschkov V 1970. Biologie und verbreitung des grieshischen frosches (Rana greace) inBulgaria. Academie Bulgare des Sciences, Bulletin de l'Institut de Zoologie et Musee Tomme XXXI: 5-12.

Blaustein AR. Keisecker JM 2002. Complexity in conservation: lessons from the global decline of amphibian populations. Ecology Letters, 5, 597-608.

Camera BF. Krinski D. Calvo IA 2014. Diet of the Neotropical frog Leptodactylus mystaceus (Anura: Leptodactylidae). Herpetology Notes, 7, 31-36.

Casimir YB. N'dédé TD. Adjéhi D. Moussa C. Bassa AY. Koffi MD. Agathe F. 2016. Prevalence et potentiel de virulence in vitro d'Aeromonas sp. chez la grenouille comestible Hoplobatrachus occipitalis (Ranidae) collectée dans le Centre Ouest de la Côte d'Ivoire. International Journal of Innovation and Applied Studies, 18: $502-511$

Collins JP. Storfer A 2003. Global amphibian declines: Sorting the hypotheses. Diversity and Distributions, 9: 89-98. https://doi.org/10.1046/j.1472-4642.2003.00012.x

Cunningham AA. Matthew WP. Katie B. Liam F. 2015. Emerging disease in UK amphibians. Veterinary Record, 176: 468 http://dx.doi.org/10.1136/vr.h2264

Das I 1996. Folivory and seasonal changes in diet in Rana hexadactyla (Anura, Ranidae). Journal of Zoology, 238: 785-794. DOI: 10.1111/j.1469-7998.1996.tb05430.x

De-carvalho CB. Freitas EB. Faria RG. Batista RC. Batista CC. Coelho WA. Bocchiglieri A 2008. Natural history of Leptodactylus mystacinusand Leptodactylus fuscus (Anura Leptodactylidae) in the Cerrado of Central Brazil. Biota Neotropica, 8 : 1676-0611. http://dx.doi.org/10.1590/S1676-06032008000300010.

Delvare G. Abertenc HP 1989. Les insectes d'Afrique et d'Amérique tropicales. Clés pour la reconnaissance des familles. Monpellier : CIRAD-GERDAT, 302 p. ISBN 2-87614-023-3

Evans M. Lampo M 1996. Diet of Bufo marinus in Venezuela. Journal of Herpetology, 30, 73-76. DOI: $10.2307 / 1564710$.

Foden WB. Butchart SH. Stuart SN. Vié J-C. Akçakaya HR. Angulo A. Lyndon M. Alexander G. Emre T. Long C. Simon D. Vineet K. Rodolphe B 2013. Identifying the World's Most Climate Change Vulnerable 
Species: A Systematic Trait-Based Assessment of all Birds, Amphibians and Corals. PLoS ONE 8(6) : 65427. https://doi.org/10.1371/journal.pone.0065427.

Geistdoerfer P 1975. Ecologie alimentaire des Macrouridae, Téléostéens Gadiformes. Thèse de l'Université de Paris VI., 315 p.

Gray AE. Mulligan TJ. Hannah RW 1997. Food habits, occurrence, and population structure of the bat ray, Myliobatis californica, in Humboldt Bay, California. Environmental Biology of Fishes 49: 227-238.

Harp EM. Petranka JW 2006. Ranavirus in wood frogs (Rana sylvatica): Potential sources of transmission within and between ponds. Journal of Wildlife Diseases, 42: 307-318. DOI: 10.7589/0090-3558-42.2.307

Hirai T. Matsui M 1999. Feeding habits of the pond frog, Rana nigromaculata, inhabiting rice fields in Kyoto, Japan. Copeia, 4, 940-947. DOI: 10.2307/1447969

Hirai T. Matsui M 2001a. Food habits of an endangered Japanese frog, Rana porosabrevipoda. Ecological Research, 16: 737-743. DOI:10.1046/j.1440-1703.2001.00430.x

Hirai T. Matsui M 2001b. Diet composition of the Indian Rice Frog, Rana limnocharis, in rice fields of Central Japan. Current Herpetology, 20 : 97-103. DOI: 10.5358/hsj.20.97

Hureau JC 1970. Biologie comparée de quelques poissons antarctiques (Notothenidae). Bulletin de l'Instut Océanographique. 68 (1391): 1-250

Hynes HBN 1950. The food of freshwater sticklebacks (Gasterosteus aculeatus and Pygosteus pungitius), with a review of methods used in studies of the food of fishes. Journal of Animal Ecology, 19, 36-58. DOI: $10.2307 / 1570$

Hyslop 1980 Stomach contents analysis. A review of methods and their application. Journal of Fish Biology 17: 411-429. https://doi.org/10.1111/j.1095-8649.1980.tb02775.x

IUCN 2020. The IUCN Red List of Threatened Species. (C) International Union for Conservation of Nature and Natural Resources. Version 2020-1. https://www.iucnredlist.org ISSN 2307-8235

IUCN 2004. Red list of theartened species.www.iucnredlist.org.Downloadeded.

Jenssen TA. Klimstra DW 1966. Food habits of the Green Frog, Rana clamitans, in Southern Illinois. The American Midland Naturalist, 76: 169-182. DOI: 10.2307/2423240

Kats LB. Ferrer RP 2003. Alien predators and amphibian declines: review of two decades of science and the transition to conservation. Diversity and Distributions 9, 99-110.

Klas-Douwe B. Dijkstra viola clausnitzer 2014. The dragonflies and Damselflies of Eastern africa. Handbook of all odonate from sudan to Zimbabwe. Studies in Afrotropical zoology, vol 298. Tervuren: Royal museum for central Africa. $263 p$.

Lauzanne 1 1975. Régime alimentaire d'Hydrocyon forskalii (Pisces, Characidae) dans le lac Tchad et ses tributaires. Cahiers ORSTOM.Série Hydrobiologie, 9 (2), 105-121.

Lips KR. Burrowes PA. Mendelson JR. Parra-Olea G 2005. Amphibian declines in Latin America: widespread population declines, extinctions, and impacts. Biotropica, 37: 163-165. DOI: 10.2307/30043168

Low P. Török J 1998. Prey size selection and food habits of Water Frogs and Moor Frogs from Kis-Balaton, Hungary (Anura: Ranidae). Herpetozoa, 11: 71-78.

Magnusson WE. Lima PA. Silva WA. Araújo MC 2003. Use of geometric forms to estimate volume of invertebrates in ecological studies of dietary overlap. Copeia, 1:13-19. DOI: 10.1643/00458511(2003)003[0013:UOGFTE]2.0.CO;2

Maneyro R. Naya DE. Rosa I. Canavero A. Camargo A 2004. Diet of the South American frog Leptodactylus ocellatus (Anura, Leptodactylidae) in Uruguay. Iheringia, Série Zoologia, 94, 1678-4766. https://doi.org/10.1590/S0073-47212004000100010

Maragno FP. Souza FL 2011. Diet of Rhinella scitula (Anura, Bufonidae) in the Cerrado, Brazil: the importance of seasons and body size. Revista Mexicana de Biodiversidad, 82: 879-886. DOI: 10.22201/ib.20078706e.2011.3.693

Maxwell SL. Richard A F. Thomas Brooks, James E. Watson M. 2016. Biodiversity: The ravages of guns, nets and bulldozers. In Nature, 536: 143-145. DOI: $\underline{10.1038 / 536143 \mathrm{a}}$

Needham J. Needham RP 1974). A guide to the study of fresh - water Biology. Fifth edition revised and enlarged. Published by Holden - day, 500 Sansome Street, San Francisco, California 94111: 108 p

Neveu A 2004. La raniculture est-elle une alternative à la récolte ? Etat actuel en France. INRAE Productions Animales, 17(3) : 161-175. https://doi.org/10.20870/productions-animales.2004.17.3.3587

ORSTOM 1973 «Dictionnaire Des Villages Du Fako Village Dictionary Of Fako Division » [archive], sur http://horizon.documentation.ird.fr/ [archive], p. 76.

Parker ML. Goldstein MI 2004. Diet of Rio Grande leopard frog (Rana berlandieri) in Texas. Journal of Herpetology, 38: 127-130. DOI: 10.1670/19-03N

Parmesan C. Yohe G 2003. A globally coherent fingerprint ofclimate change impacts across natural systems. Nature, 421: 37-42. 
Pazinato DMM. Trindade AO. Oliveira SV. Cappellari LH 2011. Dieta de Leptodactylus latrans (Steffen, 1815) na Serra do Sudeste, Rio Grande do Sul, Brasil. Biotemas, 24, 147-151. DOI: 10.5007/2175$7925.2011 \mathrm{v} 24 \mathrm{n} 4 \mathrm{p} 147$

Pinkas I. Oliphant MS. Iverson ZL 1971. Foods habits of albacore blue fin, tuna and bonito in California waters. State of california the resources agency department of fish and game. Fish bulletin 152.

Rodrigues DJ. Uetanabaro M. Prado CPA 2004. Seasonal and ontogenetic variation in diet composition of Leptodactylus podicipinus (Anura, Leptodactylidae) in the southern Pantanal, Brazil. Revista Espanola de Herpetologia, $18: 19-28$.

Rosecchi E. Nouaze Y 1987. Comparaison de cinq indices utilisés dans l'analyse des contenus stomacaux. Revue des Travaux de l'Institut des pêches maritimes, 49, 111-123.

Ruchin AB. Ryzhov MK 2002. On diet of the Marsh Frog (Rana ridibunda) in the Sura and Moksha Watershed, Mordovia. Advances in Amphibian Research in the Former Soviet Union, 7: 197-205.

Sabagh LT. Carvalho-e-Silva AMPT. Rocha CFD 2012. Diet of the toad Rhinella icterica (Anura: Bufonidae) from Atlantic Forest Highlands of southeastern Brazil. Biota Neotropica, 12, 1-5. DOI: 10.1590/S167606032012000400027

Sanabria EA. Quiroga LB. Acosta JC 2005. Dieta de Leptodactylus ocellatus (Linnaeus, 1758) (Anura: Leptodactylidae) en un humedal del oeste de Argentina. Revista Peruana de Biologia, 12: 472-477. DOI: 10.15381/rpb.v12i3.2424

Santos EM. Almeida AV. Vasconcelos SD 2004. Feeding habits of six anuran (Amphibia: Anura) species in a rainforest fragment in Northeastern Brazil. Iheringia Série Zoologia, 94: 433-438. DOI: 10.1590/S0073$\underline{47212004000400014}$

Solé M. Rödder D 2010. Dietary assessments of adult amphibians. In Amphibian ecology and conservation: a handbook of techniques (C.K. Dodd Junior, eds.). Oxford, University Press, p.167-184.

Solé M. Diasi R. Rodrigues EAS. Marciano-junior E. Branco SMJ. Cavalcante KP. Rodder D 2009. Diet of Leptodactylus ocellatus (Anura: Leptodactylidae) from a cacao plantation in southern Bahia, Brazil. Herpetology Notes, 2: 9-15.

Teixeira RL. Schineider JAP. Giovanelli M 1999. Diet of the toad Bufo granulosus (Amphibia, Bufonidae) from sandy coastal plain in southeastern Brazil. Bol. Mus. Biol. Mello Leitão (N. Sér.) 10:29-31.

Teletchea F. 2017. Wildlife Conservation: Is Domestication a Solution? In book: Global Exposition of Wildlife Management, Publisher: Intech, Editors: Gbolagade Stephen A. Lameed, pp.1-22. DOI: 10.5772/65660

Tiogué TC. Nguenga D. Tekwombuo J. Tekou G 2015. Intestine morphometrics and feeding habits of the African carp. Labeobarbus batesii (Cyprinidae, Teleostei) in the the Mbô Floodplain Rivers. Journal of Biology and Nature, 3: 1-9. http://www.ikpress.org.

Vences M. David V. Frank G. Henner B. 2004. Multiple overseas dispersal in amphibians. Proceedings of the Royal Society B: Biological Sciences, 270(1532): 2435-42. https://doi.org/10.1098/rspb.2003.2516

Voordouw MJ. Adama D. Houston B. Govindarajulu P 2010. Prevalence of the pathogenic chytrid fungus, Batrachochytrium dendrobatidis, in an endangered population of northern leopard frogs, Rana Pipiens. BMC Ecology, 10 (6):1472-6785. DOI: 10.1186/1472-6785-10-6

Walther GR. Post E. Parmesan C. Convey P. Menzel A. Beebee TJC. Fromentin JM. Hoegh-Guldberg O. Bairlein F 2002. Ecological responses to recent climate change. Nature, 416: 389-395. DOI: $10.1038 / 416389 \mathrm{a}$

Werner EE. Wellborn GA. McPeek MA 1995. Diet composition in post metamorphic bullfrogs and green frogs: Implications for interspecific predation and competition. Journal of Herpetology, 29, 600-607. DOI: $10.2307 / 1564744$

Whitaker JO. Rubin-Junior D. Munsee JR 1977. Observations on food habits of four species of spadefoot toads, genus Scaphiopus. Herpetologica, 33, 468-475. DOI: 10.2307/3891718

Whitaker Jr JO. Cross SP. Skovlin JM. Maser C 1981. Food habits of the Spotted Frog (Rana pretiosa) from managed sites in Grand County, Oregon. Northwest Science, 57, 147-154. 